\title{
Hybridity of the Jewish Diaspora Characters in Pearl S. Buck's Novel Peony (1948)
}

\author{
Ayu Ratna Ningtyas \\ Universitas Muhammadiyah Purwokerto \\ ayuratna90@gmail.com
}

Article History:

First Received:

$23 / 11 / 2020$

Final Revision:

$26 / 12 / 2020$

Available online:

$30 / 12 / 2020$

\begin{abstract}
This research aims to investigate the hybridity of the Jewish diaspora characters in Pearl Sydenstricker Buck's novel Peony (1948). Peony (1948) raises identity issues especially within the Jewish diaspora characters. The qualitative method is used in collecting, interpreting, and analyzing the novel Peony as the main data. The data analysis uses the theory of identity and hybridity in analyzing characters in the novel. The theory of identity is used to analyze the intercultural interactions among the characters of different ethnic backgrounds which shapes a contestation of identity among characters in the novel. Hybridity theory is also used to analyze how Jewish diaspora characters transform into hybrid characters in responding the contestation of identity. Through the observation of how the contestation of identity happens among the characters, this research shows that the Jewish diaspora characters in Peony use hybridity as strategy to win the contestation of identity among characters in the novel.
\end{abstract}

Keywords: contestation, hybridity, identity, intercultural interaction

\section{http://ios.unsoed.ac.id/index.php/ies}

\section{INTRODUCTION}

As a diaspora writer, Pearl Sydenstricker Buck often reflects her experience as diaspora community in many of her works, one of them is in her novel Peony (1948). This novel talks about Jewish-diaspora family, the family of Ezra, who have lived for generations in China. Ezra's family has many Chinese servants, one of them is Peony-a young smart Chinese girl- and lives surrounded by Chinese culture and society. The intercultural interactions among characters in the novel basically does not run smoothly. Different ethnical background between Jewish diaspora characters and Chinese characters in the novel leads to a complex intercultural interaction among them. Peony raises the issue of cultural struggles in preserving complex identity of the characters.

Most of Buck's works always are best sellers, but Peony is different. This can be seen from a commercial side and the lack of reviews as well as critical analysis of this novel (Ruiqi Ma, 2003: 179). In previous studies on the novel Peony, most of the studies highlighted conflicts over identity. However, most of them are still limited to only focusing on the issue of the formation of Jewish diaspora 
characters' new identity which is marked by cultural assimilation so that the original identity is completely detached (Cheung, 2003; Liao, 1995; Ruiqi Ma, 2003), or discussing the relationship between the issue of identity in Peony and Buck's critics toward political discourse of America which was discriminative and gender-biased in the early 20th century (Okuma, 2008). Apart from several studies that have been mentioned above, there were also two novel reviews which also discussed the issue of identity in Peony. The first review was written by Jennifer Cody Epstein (2008) entitled "In Bloom: Pearl S. Buck Breathes Life into a Disappearing Chinese Community". She highlights the problem of identity and the process of struggle as well as defeat which means the loss of Jewish diaspora characters' identity in the novel because it had merged with Chinese society. The second review entitled "Peony Offers Rare Glimpse into World of Chinese Jews" was written by Hilary Daninhirsch (2011) and examines the assimilation process along with the loss of original identity of Jewish diaspora characters in Peony.

The studies above have not yet touched the aspect of hybridity of Jewish diaspora characters in the novel which also plays a very important role in contestation of identity in the intercultural-interactions among characters. This opens up chance for further research on the novel Peony. Characters in the novel both Jewish characters and Chinese characters- define identity issues differently. The theory of identity from Hall (1997) will be used to analyze how Jewish and Chinese characters in the novel see their identity. This research does not discuss all the characters in the novel Peony, instead, only the characters considered as the most representative which are the characters who are intensely involved in the conflicts related to contestation of identity. In this case, the Jewish characters observed are Ezra, David, and Madame Ezra, while the Chinese character observed is Peony.

Hall (1997) calls cultural identity as a representation that is not permanent because it is an incomplete production or construction but is always in a process of change and is formed from within a group. As part of the diaspora community, Jewish characters in the novel face various contradictions in interpreting cultural identities that continue to move dynamically. According to Hall (1997), the past and history have a close relationship in shaping cultural identity. Jewish character in the novel, such as Madame Ezra deals with the contradictions of cultural identities that connect the past as a source of her present and future cultural identity elements. On the contrary, other Jewish characters, such as Ezra and David see their cultural identity as an unfinished construction process, the process of interpreting cultural identity cannot be separated from the dimension of space and time.

In general, the issue of identity in Peony is interpreted as an issue related to religion, considering that the discussion of the context of the identity of Jewish characters cannot be separated from the discussion of Jewish religion itself. The two are difficult to separate because Jewish as a religion is only adopted by the Jews (Hermawati, 2005). Identity issues are differently defined by the characters and it creates a kind of group polarization, which are the essentialist and the nonessentialist. The essentialists see identity as something solid and unchanging. This is represented by one of the Jewish characters like Madame Ezra. On the other hand, Ezra and David, under the influence of Peony, see their identity as something fluid. Thus, a contestation of identity is inevitable. 
The contestation of identity between the essentialist and non-essentialist characters then encourage them to carry out various strategies to maintain their existence in this contestation. The strategic efforts made are also able to provide an in-between space and are very conducive to the growth of hybridity (Bhabha, 1994). The concept of hybridity from Homi Bhabha is also used to sharpen the analysis toward the indication of appearance of hybrid characters in the novel.

Hybridity is also interpreted as syncretism, which is defined as everything that occurs because of a mixture and combination in cultural exchange process (Kalra, Kaur and Hutnyk, 2005: 71). This terminology is also closely related to the terminology of the diaspora which is called as a category on the 'edge' or connected point of the diaspora, which describes cultural crossovers. This situation is easily found in Ezra's family as Jewish diaspora characters in the novel. Ezra's family stands as members of diaspora who meet native people (Chinese characters) in the migration area. In the process of intercultural dialogue, each culture leaves its center and approaches the border which becomes a place of contact between cultures. These 'in-between' spaces are also called third spaces (Bhabha, 1994: 37). Ezra's house is one of the examples of place of contact between Jewish and Chinese cultures where the characters in it will deal with. Then, through this third space, the process of reinterpreting various aspects of a culture takes place and allows the articulation of a non-essentialist characters in the novel to occur.

According to Bhabha (1994), through this exploration of the third space, polarity and ethnocentrism can be blurred. Hybridity is the result of various negotiations carried out in this third space, which treats the two cultures that flank it equally (Bhabha, 1994: 28). This condition is an ideal condition for the development of hybrid characters in the novel since the Jewish diaspora characters, such as Ezra and David may embrace both Jewish and Chinese culture at the same time. This process can produce hybrid characters in the novel who internalize the various advantages of each culture. This third space is always in the process of rearticulation that rejects the polarity of "us" or the marginalization of "them" and questions the boundaries of both to construct something new, the hybrid characters like Ezra and David. According to Bhabha, the third space is always in a continuous process of rearticulation, reinterpretation and definition due to constant friction between the intersecting cultures. Thus, the hybridity that is formed in this third space is not steady because it is constantly rearticulating along with the changing environment that forms it.

Hybridity never stops at a precise identity, but continues to be in the process of becoming (Bhabha, 1994: 25). This opinion is in line with the views of non-essentialists regarding identity as a never-ending process. The concept of hybridity is then used to show the important influence of hybridity on Jewish diaspora characters who are non-essentialist in the novel. Hybridity positions the hybrid characters in the novel to be in the middle and able to move into the two cultures, both Jewish and Chinese. Therefore, this research examines how the hybridity of the Jewish diaspora characters in the novel are used in the contestation of identity. As an important aspect, the discussion over hybridity in Peony has not been done in previous studies, so it is interesting to do a deeper research on this issue. This research will provide a new point of view on reading the novel of Peony by providing an overview on Hall's identity theory and Bhabha's 
hybridity theory at first. Secondly, it is followed by an overview of the research method. Then, the analysis of the data will be explained in the result of the discussion. The data will be collected, interpreted and selected from the narration, characters' action and thought in the novel. Then, analyzing the data by using theory of identity to explore the contestation of identity among characters in Peony and theory of hybridity to research hybridity of Jewish diaspora characters in the novel. At last, conclusion will be derived from the findings of the research.

\section{RESEARCH METHOD}

This research uses a qualitative approach. The data collection method used is the library-research method through close-reading techniques. The main data is Pearl Sydenstricker Buck's novel Peony (1948). To support the main data, this research also uses books, journals, articles or other researches which are relevant with the analysis. After reading and re-reading the novel, this research begins by collecting data and then interpreting and analyzing the data from the narration, characters' action and thought in the novel. At this stage, this research uses theory of identity to see groups polarization among characters and the contestation of identity in Peony. Afterwards, an observation using theory of hybridity is conducted to reveal hybridity of the Jewish characters such as, Ezra and David, as the dominant strategy to win the contestation of identity they are in. This research does not discuss all the characters in Peony, only the most representative characters from Jewish and Chinese characters who are most intensely involved in the contestation of identity. The last step of this research is deriving a conclusion from the findings of the research.

\section{RESULT AND DISCUSSION}

\section{Contestation of Identity among Characters in Peony}

Peony tells a story about the life of the Jewish diaspora family in Kaifeng, China, the family of Ezra's. Ezra lives with his wife Madame Ezra or Naomi and their only son named David. Ezra is a mixed Chinese Jew whose mindset is very open so he does not impose too much Jewish religion and culture in his home. On the other hand, Madame Ezra, who is still of pure Jewish descent, has a rigid mindset on issues of identity. The Ezra family had a number of Chinese servants, one of whom was Peony. Peony was different from the other servants in Ezra's house, she could read and write. Madame Ezra intends to pair David with a Jewish girl named Leah who is the daughter of a rabbi, the spiritual leader of the Jewish religion. However, in the end, under the influence of Peony, David married Kueilan, a Chinese girl, the daughter of a rich Chinese merchant named Kung Chen.

Intercultural interactions among characters in the novel are observed by analyzing the narration and characters' action and thought in the novel. This interaction tinged with efforts to influence; change; and persist with each other among the characters. This leads to a group polarization, essentialist and nonessentialist groups. Madame Ezra, as an essentialist character, wants to keep Ezra and David separated from Chinese culture and society around them. She made various efforts to preserve Jewish culture and religion in her family, for example by pairing David with Leah, a Jewish girl. Madam Ezra, in this stage, is trying to 
influence and rule other characters, David and Ezra. Meanwhile, non-essentialists characters interpret identity as a fluid and dynamic thing. In the novel, this is represented by a Chinese character named Peony, which through her attempt finally David marries to a Chinese girl, Kueilan.

Madame Ezra, as a diaspora of pure Jewish descent, sees her identity as an original identity that will never change. Hall named it the "displaced homeward journey" (1997: 232). This means that the identity that is sought on her journey is an entity of authentic and permanent identity that will never be found. This understanding of Madame Ezra's cultural identity can be reflected in her efforts to cultivate Jewish values and teachings within her household, especially toward her son, David. This can be seen in the excerpt below:

David broke in, "But I don't want to go away. This is where I was born, Mother-here, in this house."

Madame Ezra dropped her persuasion. Honest temper blazed in her full face. "Dare to speak so to your mother!" she shouted. "God grant us the chance to go back to the land of our fathers before we die - you and I and your father and all our house!"

Ezra coughed behind his hand. "I couldn't leave my business, Naomi." (Buck, 2012, p.14).

The above quotation shows the upheaval of understanding "the land of our fathers" between David, Madame Ezra and Ezra. On the one hand, Madame Ezra saw the father's land as an important part that could not be separated from her. On the other hand, David and Ezra tend to refuse to return to their ancestral land because they feel comfortable in China. For both Ezra and David, the understanding of the father's land like Madame Ezra is no longer relevant to the current situation of her family who can live peacefully and happily in China. Ezra is a mixed Chinese Jews so that he can access both Jewish and Chinese culture at the same time. This clearly had a distinct influence on Ezra's mindset in understanding the ancestral lands. Although Ezra's father as a Jew had cultivated Jewish values and teachings to Ezra, but at the same time his mother, a Chinese woman, also raised Ezra with Chinese culture. This had a significant impact on Ezra's perspective. As a successful entrepreneur in Kaifeng, Ezra also has many business relations with Chinese people. This shows that the socio-cultural life of Ezra cannot be separated from both Jewish and Chinese culture. Therefore, Ezra can be open to Chinese culture and not refuse to assimilate with Chinese society.

David has a socio-cultural environment similar to Ezra. David's interaction with his social environment around him also affects David's understanding on his identity. David made friends with many young Chinese, he also regularly learned Confucian values from his Chinese teacher, and had many servants in the house who were all Chinese, including Peony. This had an effect on David as he grew to be a critical character and see the ancestral lands differently from his mother. Therefore, the persistence in defining the ancestors' land is now being contested in the Jewish characters themselves just like in Ezra and David. This issue cannot be separated from the existence of intercultural interactions which take place in the social environment in where the characters live. In the above excerpt, Ezra and David question identity which is built on the foundation of common history and ancestry. They reject a definition of cultural identity that reflects shared historical experiences and a collective cultural code that is stable, continuous and 
unchanging (Hall, 1997). Ezra and David represent the unfinished search for identity by relying only on understanding past identities regardless of the context of space and time in the present. From the above excerpt, it can be concluded that Madame Ezra, Ezra, and David are involved in the complexity of contestation of identity discourse. Madame Ezra's resistance did not run smoothly but met with conflict over the contestation. This clarifies the existence of contestation in the identity discourse within Jewish characters.

The process of dispute over defining identity is not only within oneself among the Jewish characters in Ezra's family, efforts to change and influence from the non-Jewish characters are also made. Epstein (2008) mentions the main role of Peony which makes David marry Kueilan. This marks Peony's confrontation to beat Madame Ezra's efforts to defend Jewish values and teachings by pairing David with Leah. Peony is the most prominent servant in Ezra's house and occupies an important position especially in the contestation of identity in the novel. Peony knows that she loves David but she can put her feeling aside and undertakes an effort to remain being someone whom David depends on, although not as a life partner. Her success was marked by David's marriage to Kueilan, a Chinese girl whom she chose to become David's wife. The following excerpt shows Peony's important role in defeating Madame Ezra's resistance to Chinese culture and even the Chinese people.

She ran on, but not to David's room. She went to his schoolroom, now empty, and at the table in haste she took up the writing brush, put off its cover, and then made a little ink. She had kept the unfinished poem in her breast, and now she drew it out. Thinking fast and drawing her brows together, she quickly wrote three lines more upon the empty sheet.

"Forgive me, David," she whispered, and replacing pen and ink, she ran back to her own room. Opening a secret drawer in her desk, she took out a purse with money in it, the gifts that guests gave her and the coins that Ezra tossed her sometimes when he was pleased with her. Putting this too into her bosom, she slipped though passageways to the Gate of Peaceful Escape at the very back of the compound, that little secret gate which all great houses have, so that in time of the anger the people, when they storm the front gates of the rich, the family itself can escape by it. (Buck, 2012, p.36).

Peony's role in pairing David and Kueilan is by sending the poetry she wrote to Kueilan on David's behalf. Knowing David did not finish the poetry for Kueilan, Peony took and kept David's poetry writing. Unbeknown to David, she added three lines of poetry to complete David's unfinished poem and then sent the poem to the Kueilan house. Peony handed the poem to Chu Ma, the Chinese woman who served Kueilan. As a servant, Peony shows ingenuity by arranging this systematic plan. This indicates Peony 's ability and skill as not just an ordinary servant like the other servants in Ezra's house. Peony is good at writing and reading. In the above excerpt, Peony shows her ability to write poetry which means that she also has an interest and proficiency in literature.

The excerpt above at the same time reflects the confrontation that Peony did to thwart Madame Ezra's resistance to perpetuating Jewish religion and culture in Ezra's house. Peony deliberately devises a plan that can prevent David's arranged marriage with the Jewish girl, Leah. Instead, it was David's marriage to a 
Chinese girl according to Peony's wishes that happened. The marriage of David and Kueilan is Peony's strategy to defeat Madame Ezra's resistance. Peony's confrontation to Madame Ezra was not overtly seen. It becomes interesting because as a person of the lower-class social status in Ezra's house, Peony is able to strategize to influence David's belief in choosing Kueilan. This strategy is reflected in the above excerpt. The peak point of the contestation that took place in Ezra's house was when David married Kueilan. As previously mentioned, Madame Ezra tried hardly to defend Jewish religion and culture, one of which was by marrying David off to a Jewish girl, Leah. After Leah's death and Peony's influence on David's beliefs, Madame Ezra was unable to prevent David married a Chinese girl.

Contestation of Identity among Characters in Peony
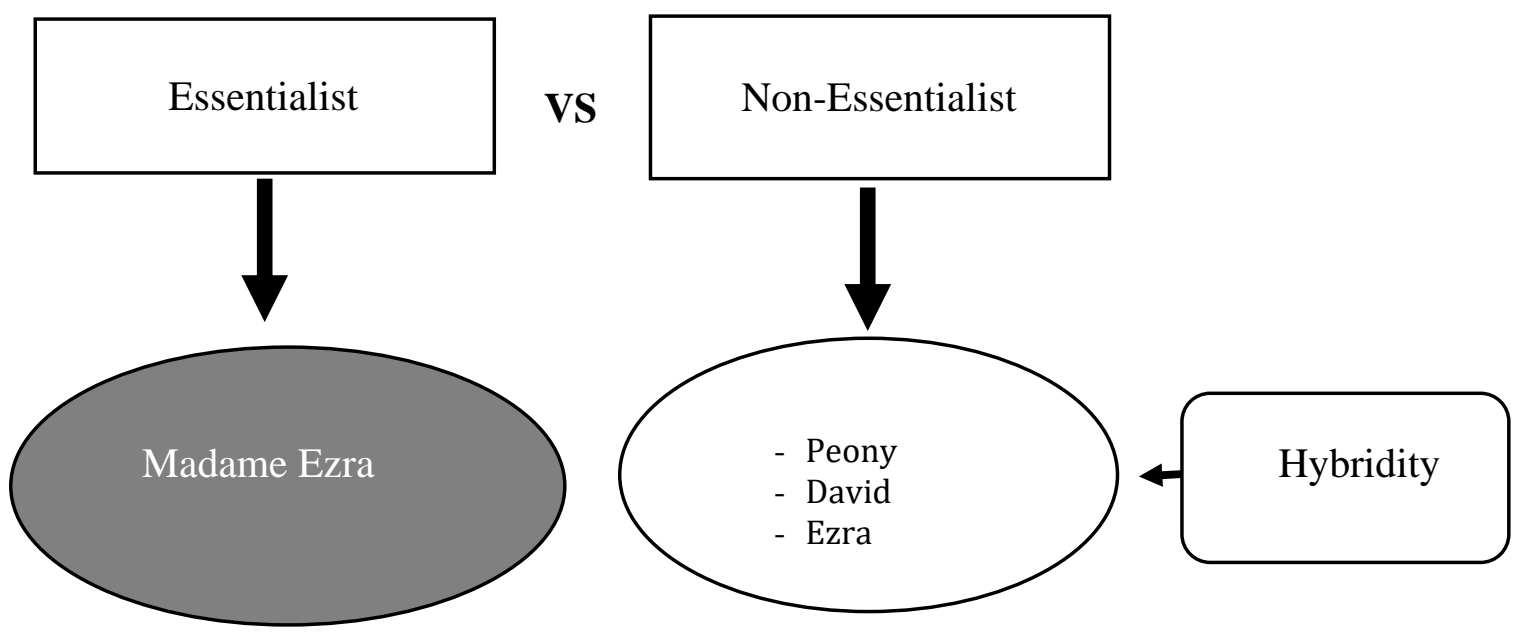

The diagram above sums up the group polarization shapes contestation of identity among the characters and each member of the groups tries to influence and dominate each other. What makes it interesting is that issues of identity are not only contested between Jewish and Chinese characters but also among Jewish characters themselves. This means that intercultural interactions which tinge the life of Jewish diaspora characters, such as David and Ezra, are actually the process of negotiation which fills out contestation of identity and shows the essence of searching for cultural identity which will never know the word over as Hall (1997) stated before. In the diagram, character of Madame Ezra is colored in black to emphasize the loss of hers in the contestation of identity. Based on the diagram, it also can be seen how hybridity greatly plays an important role in the characters of David and Ezra responding to contestation of identity. This will be further explained in the next part.

\section{Hybridity of The Jewish Diaspora Characters in Peony}

The previous discussion shows that the characters in the novel of Peony are in a space where two cultures, Jewish and Chinese, intersect. This meeting point colored by contestation constructs a formation of the third space. The third space according to Bhabha (1994) is very open to opportunities for the growth of hybridity. This third space by Bhabha is called to contain the characteristics of 
neither the one nor the other (1994: 53) which is a way to articulate new possibilities. This third space in the novel creates a hybrid characters, such as David and Ezra, which are the result of a mixture of the two cultures, Jewish and Chinese. The ambivalent and ambiguous situation appear the emergence of the hybrid identity seen in the characters David and Ezra. Peony is one of the figures indicated to have a role in the hybrid identity of David.

Ezra greatly influenced Ezra's teaching for David. This situation encouraged David to be involved in the complexity of the socio-cultural environment both at home and outside his home. The difference in views on identity between David's parents allowed David to have a very fluid understanding on the identity discourse. This fosters a hybrid identity in David. On the one hand, Ezra's hybridity which is very open to culture can be seen from the following quote.

"It's a pity," Ezra said absently. "Pigs' fat, eh? Of course I'm not orthodox -- hmm -- "He took a cake and ate it quickly. "Very good, too. Pity! Well, yes, it won't do in this house. " (Buck, 2012, p.11).

Ezra loved this food. In his own house beneath his wife's eyes he was scrupulous as to food, but when he was alone and free he ate whatever was praised by his host, and tonight his willing belly was warm and waiting. (Buck, 2012, p.78).

From the beginning, Ezra has displayed a hybrid identity to position himself in the ongoing contestation of identity. Hybridity was one of the ways for Ezra to negotiate with Madame Ezra. David did not negotiate with Madame Ezra because his hybrid cultural ideology experienced many conflicts, including when he was shaken by the massacres of Jews outside China which is showed in the narration of the novel. Therefore, David's hybridity is not simple because of his unstable condition. In contrast to David, Ezra used his hybrid identity in a mature manner. Instead, he negotiated with Madame Ezra by showing himself to be a Jew, although not a religious Jew. At the same time Ezra did not show himself to be completely Chinese even though he had Chinese blood from his mother.

In the above excerpt, Ezra can move freely into two places at once. He can eat foods containing pork when he gathers with Chinese people. The first excerpt was when he was enjoying a delicious pork-fat cake which Peony would throw away at Madame Ezra's orders. The second one is at a dinner with Kung Chen. In both excerpts, Ezra was well aware that he would avoid foods forbidden in Jewish religion when he was with Madame Ezra. On the other hand, when he was with Peony and Kung Chen, he could eat as much as he wanted without any restrictions. Through the two excerpts above, it can be seen how Ezra can use hybridity to deal with and negotiate with Madame Ezra and also at the same time still merge with his surroundings, which are predominantly Chinese. He can live his life happily. He can satisfy his desire to eat anything without the burden of prohibitions or sins against foods that are forbidden in Jewish religion, but can also maintain a stable relationship in his household with Madame Ezra by staying away from these forbidden foods when he is with Madame Ezra. At this point, Ezra was well aware of the benefits he would get from hybridity.

Ezra and David stated that they did not want to return to their ancestral lands. Both of them have Jewish ancestry but do not feel the need to return to their ancestral lands because they feel very welcome in China. Ezra and David's 
understanding of the ancestral land thus shows that they still realize that they are Jewish blood, but at the same time also love Chinese land as home. In Madame Ezra's view, Ezra is ambiguous because of his perspective. He has Jewish blood, received a Jewish education from his father, married a Jewish woman, but had no will to return to his ancestral land. This contradicts the concept of a Jew in Madame Ezra's point of view, who should have ties to the ancestral land as the goal of returning one day.

"Naomi, I am willing now that David should be taught the law and the prophets," Ezra had said.

"Thank you, Ezra," she had replied, and had subdued her joy.

"There is nothing we can do about our kinsfolk abroad," Ezra had gone on. "The sensible thing for us is to stay here, where we at least are safe."

"Until such time as a prophet comes forward to lead us home," Madame Ezra had answered gently.

Ezra had coughed. "Well, my dear," he said. He patted her hand. "I sometimes wonder why we should ever leave China. Four generations we have been here, Naomi, and David's children will be the fifth. The Chinese are very kind to us. " (Buck, 2012, p.53).

The excerpt above is Ezra's conversation with Madame Ezra. On the one hand, Madame Ezra continues to emphasize the importance of returning to their ancestral lands as the ultimate goal. On the other hand, Ezra sees that their family did not need to leave China because they were very well welcomed in China. Ezra's attitude in the above excerpt reflects a hybridity. Ezra agrees on the importance of David starting to take Jewish religion and culture seriously, but at the same time Ezra still rejects to return to the land of the ancestors. Ezra's perspective on ancestral land did not mean that he would leave Jewish religion and values. By continuing to embrace and be open to Chinese culture, Ezra maintained his attachment to Jewish religion and culture. This at the same time emphasizes Ezra's hybridity. He is choosing to stand and embrace two cultures, both Jewish and Chinese. The hybridity matters greatly and helps Ezra to embrace Chinese local culture without leaving his Jewish religion and culture.

Hybridity also gives Ezra its own advantages. As an entrepreneur, Ezra cannot deny that hybridity has a good and beneficial effect on his business. The Chinese around him were able to cooperate well with him. The image of Ezra and his family's ancestors from the first generation was that of a smart and successful entrepreneur. This image makes the Chinese people respect the Ezra family and welcome them very well. Therefore, the economic factor that gives the Ezra family the leading social status in China was an advantage of hybridity. Ezra realizes that hybridity is not only allowed him to win the contestation with Madame Ezra in the contestation of identity discourse, but also provided economic benefits for his business.

Ezra shrugged and spread out his big hands, palms upward. "Well, my dear, you see the advantages. I am an importer of foreign goods, he is a merchant with shops in a dozen big cities, you see. After all, we are living in China. " (Buck, 2012, p.12).

The excerpt above shows how Ezra convinced Madame Ezra of the benefits they would receive if David married the daughter of Kung Chen, a wealthy and 
successful merchant in China. Ezra understands that mixed marriages with Chinese people is inevitable because they live in China. This once again confirms Ezra's hybridity because he does not agree with Madame Ezra in maintaining the purity of a Jewish identity in the midst of a predominantly Chinese culture. By bringing a counter discourse to marrying David off to Kung Chen's daughter, Ezra simultaneously shows the benefits they would get if they embraced Chinese culture. It should be emphasized that Ezra's decision to marry David to Kueilan as a whole was not entirely based on economic motive. Ezra prioritizes David's happiness when he decides to marry David to Kueilan after the tragedy of Leah's suicide which also injured and threatened David's life. Even at that point David didn't really want a marriage because he was still feeling guilty about Leah's death. However, the economic motive cannot be completely eliminated from Ezra's choice of embracing Chinese culture through the marriage of David and Kueilan.

David's hybrid identity began to emerge when he was able to criticize his mother's views on ancestral land. David considered Chinese land as home, while Madame Ezra considered Chinese land as foreign land. Madame Ezra believes that only their ancestral land was their final destination as Jews. Here is an excerpt that further emphasizes David's hybridity. One indication of David's hybrid identity is his lifestyle that resembles Chinese youth.

It was true - theirs was a people separate and apart, a people of destiny, appointed by Jehovah, the One True God. He felt now, with deep strange guilt, that he had denied God by his careless gay life in a heathen country. While his people had suffered and died he had laughed and played and wasted his days. He remembered the things he had loved most, the gambling in Chinese teahouse, the idle summer afternoons on the lake where he and his young Chinese friends floated in pleasure boats, the smell of lotus flowers, the music of violin and flute in a courtyard in the moonlight. (Buck, 2012, p.52).

In the above excerpt, David is enjoying life with his friends. He is very fond of gambling in teahouses and having fun with his Chinese friends. David reflects that he did not resist Chinese culture so he was able to embrace local culture to become a part of him. David is surrounding by his young Chinese friends and Chinese servants in his house, it made him easy to embrace Chinese culture. This encourages David to make assimilation easier and it is not difficult to survive in foreign lands. However, David could not just let go of the Jewish religion and values which were also internalized in him. Madame Ezra raises David with strong Jewish teachings so that David also adopted these values, for example, he still believed in God in Jewish religion. However, David also still lives a lifestyle like the Chinese youth. The hybridity in David is quite complex. This hybridity plays an important role in David to survive and ultimately win in the contestation of identity arena. David's hybridity was largely influenced by Peony.

The explanation about David and Kueilan's marriage is used as an attempt to secretly confront Peony with Madame Ezra. At this stage, the marriage also opened up opportunities for David's hybridity. Peony aims to fully assimilate David into Chinese culture. However, Peony's endeavors also encourage hybridity. After marrying Kueilan, David apparently still kept his spirituality and didn't leave it just because he married a Chinese girl. Although he absorbs Chinese culture, at the 
same time, his spirituality as a Jew was still in him. The excerpt below captures how David's spirituality is maintained.

"You know my mother and I planned to take the journey westward to the land of our ancestors. I have a wish to make that journey now, alone, "he paused and then he said abruptly," There is something restless in me."

"There is something restless in you," Peony repeated. She felt stupid with surprise and yet she knew she needed all her wits about her.

"I feel some hidden guilt in me," David went on. "I have had the guilt ever since Leah died. Now my mother is dead. This journey would somehow be for them. " (Buck, 2012, p. 143).

Peony's goal in marrying David to Kueilan is to provide comfort to David so that he will openly embrace the local culture and slowly move away from Jewish religion and culture. However, a different response emerges because David did not in fact cultivate toward only one culture, Jewish or Chinese. In the novel, it is depicted as if David is totally merged with Chinese culture after marrying Kueilan. However, on closer observation, David is actually in a third space which is not easily defined. He does not totally leave Jewish religion and values that had been taught since he was a child, but at the same time did not fully integrate with Chinese culture.

After Madame Ezra died, David expressed his intention to Peony to go to his ancestral land. The above excerpt shows David's view on his ancestral land differently than before he married. At glance, it looks like David ended up having the same orientation with Madame Ezra about the ancestral land that is returning there as a Jew. In fact, David never agrees the land of his ancestors as a destination or a place to return to which he should be longing for, as Madame Ezra taught him. The above excerpt actually tends to show David's hybridity. David's spirituality was closely shown and kept only for him. This can be seen from David's desire to go to the ancestral land even though in the end it did not come true. David's spirituality is at the meeting point between his embracement to Chinese culture and his critical view on Jewish religion and culture itself.

The desire to return to the land of ancestor land as in the above excerpt is ambiguous and seems to contain a dualism between the spirituality drive in him which is very tightly stored and the motive of respect for his mother and Leah. This refers to David's words "This journey would somehow be for them". Therefore, David's desire to travel to the land of his ancestors opened the assumption that this was not based on faith in Jewish religion and culture as Madame Ezra had done. What prompted David to travel to the ancestral land was guilty feeling towards his mother and Leah. Therefore, the motive of faith (spirituality) and cultural attachments that underlie David to go to his ancestral land is ambiguous because he is at the point of contestation with his attachment to Chinese culture.

On the other hand, David also emphasized the attitude that he was not afraid to leave all the comforts he had on China, such as his family and business. Even the safety risks of the trip didn't deter him. This means that the Chinese land which he considers home does not make him a fully part of Chinese culture itself. The comforts that Peony originally arranged to tie David to Chinese culture did not work, because David bravely gave up all these comforts to travel to the ancestral lands. This shows that David did not actually choose to be part of both Jewish and Chinese completely. It is in a new space that forms a new identity, namely a hybrid identity. 
Peony's influence on David and Kueilan's marriage contributed to David's hybridity. David grew up with a greater awareness of the importance of hybridity in responding to the ongoing contestation. David did not hesitate to abandon the land of China and the comfort in it, but he also did not go to ancestral land solely on the basis of his Jewish faith. David's hybridity is increasingly seen when David then enjoys his life in China more calmly and comfortably. Peony's role in solidifying David's hybridity became clearer when David began to mature in conducting negotiations that enabled him to survive in contested intercultural interactions. The negotiations in question were related to David's wise attitude, who was now more careful. He realized that he was both Jewish and Chinese. He now lives in Chinese society so that he cannot separate himself from his surroundings. Being Jewish and living by embracing Chinese culture is now one of the most strategic ways for David and his future generations to survive in a complex cultural intersection space. In this way, David can deal with a contestation arena by using his hybrid identity properly. This is reflected in the following excerpt.

"We cannot live here among these people and remain separate, Father," David argued. "In the countries of Europe, yes, for the peoples force us to be separate from them by persecution. We cling to our own people there because none other will accept us, and we are martyred and glorified by our martyrdom. We have no other country than sorrow. But here, where all are friends to us and receive us eagerly into their blood, what is the reward for remaining apart? " (Buck, 2012, p. 143).

The excerpt above portraits David's hybrid identity as a strategy. This strategy is necessary, considering that he must be able to embrace the two cultures that surround him. He needs to stand with the two cultures simultaneously in order to survive in China as well. Hybridity is a prominent factor for David and Ezra in their success to win and survive in a contestation of identity. Peony's involvement in this hybridity made Peony a very knowledgeable character in the contestation of identity among the characters in the novel. Hybridity is thus a negotiation effort that does not stop at the process of accepting both cultures comfortably but also re-articulating and accommodating them continuously.

\section{CONCLUSION}

This research comes from a question about the intercultural interaction between Jewish and Chinese characters in the novel of Peony. The conflicts that occur among the characters show that these intercultural interactions are not running smoothly. Each character competes for positions to dominate and rule. By observing the intercultural interactions among the characters in the novel, it is found that there is complex contestation which is started by a groups polarization. The contestation involves the Jewish characters themselves and between Jewish and Chinese characters. In the family of Ezra's, this could be seen from the way they maintained their views of ancestral land and mixed marriages. In the contestation of identity, the hybrid characters, such as Ezra and David, prove to be able to make them survive and win the contestation. Ezra's hybridity allowed him to survive as shown by his ability to have good relations with Madame Ezra and the Chinese characters around him at the same time. Peony's success in presenting Kueilan as David's wife made hybridity plays an important role to David. Hybridity 
is one of the dominant strategies to negotiate, survive, and win the contestation of identity among the characters in the Peony.

\section{REFERENCES}

Bhabha, Homi K. (1990). "Introduction Nation and Narration" in Homi K. Bhabha. 1990. Narrating Nation. London: Routledge.

Bhabha, Homi K. (1994). The Location of Culture. London: Routledge.

Buck, Pearl. S. (2012). Peony: A Novel of China. New York: Open Road Integrated Media.

Cheung, Kai-Chong. (2003). Ethical Assimilation in Pearl S. Buck's Peony. An Early Example of Identity and Globalization. Canadian Comparative Literature Association. Soochow University/ Shih Hsin University, Taipei.

Daninhirsch, Hilary. (2001). Peony offers rare glimpse into world of Chinese Jews. Retrieved from : http://www.thejewishchronicle.net/view/full_story/10903044/article\%E 2\%80\%98Peony\%E2\%80\%99-offers-rare-glimpse--into-world-of-ChineseJews.

Epstein, Jennifer Cody. (2008). Pearl Buck breathes life into a disappearing Chinese community. Retrieved from: http://www.tabletmag.com/jewish-arts-andculture/books/881/in-bloom.

Hall, Stuart. (1997). "Cultural Identity and Diaspora” in Kathryn Woodward (ed.). 1997. Identity and Difference. London: SAGE Publication.

Hermawati. (2005). Sejarah Agama dan Bangsa Yahudi. Jakarta: PT. Raja Grafindo Persada.

Kalra, Virinder S., Raminder Kaur and John Hutnyk. (2005). Diaspora and Hybridity. London: SAGE Publications Ltd.

Liao, Kang. (1995). Pearl S. Buck: A Cultural Bridge Across the Pacific. Dissertation. UMI Company. West Virginia University.

Okuma, Taryn L. (2008). "Jews in China and American Discourses of Identity in Pearl S. Buck's Peony” in Tulsa Studies in Women's Literature, Vol. 27, No. 1, pp. 115-139. University of Tulsa.

Ruiqi Ma. (2003). All Under Heaven: The Portrayal of Chinese Women in Pearl S. Buck's Writing. Dissertation. ProQuest Information and Learning Company. University of California, Riverside. 